\title{
Implementasi Nilai Agama dan Moral melalui Metode Esensi Pembinaan Perilaku pada Anak Usia Dini
}

\author{
Ika Juhriati1, Azi Matur Rahmi ${ }^{1 凶}$ \\ Pendidikan Anak Usia Dini, Universitas Pelita Bangsa, Indonesia(1) \\ DOI: $\underline{10.31004 / o b s e s i . v 6 i 2.1147}$
}

\begin{abstract}
Abstrak
Berdasarkan fakta yang peneliti temukan di lapangan, pada saat peneliti melakukan observasi pada Taman Kanak-kanak umumnya ternyata masih kurang optimal dalam pengembangan nilai agama dan moral pada anak usia dini. Dengan kenyataan kurangnya pelaksanaan metode-metode yang dilakukan. Jenis penelitian ini adalah dengan pendekatan kualitatif menggunakan format deskriptif yaitu dengan metode observasi, wawancara dan dokumentasi. Hasil penelitian menunjukkan tentang implementasi nilai agama dan moral melalui metode esensi pembinaan prilaku di Taman Kanak-Kanak Lab. School Universitas negeri Padang telah dilaksanakan dengan baik terlihat dari cara anak mengenal tuhan, mengenal ibadah kepada Allah SWT, serta berakhlak yang baik.
\end{abstract}

Kata Kunci : implementasi; nilai agama dan moral; pembinaan prilaku; anak usia dini

\begin{abstract}
Based on the facts that researchers found in the field, when researchers conducted observations in Kindergarten, in general, they were still not optimal in developing religious and moral values in early childhood. With the fact the lack of implementation of the methods carried out. This type of research is a qualitative approach using a descriptive format, namely the method of observation, interviews and documentation. there are schools showing the Implementation of Religious and Moral Values Through the Essence Method of Behavior Development in Kindergarten Labs. School UNP has been implemented well, as can be seen from the way children know God, know worship to Allah SWT, and have good character.
\end{abstract}

Keywords: implementation; moral religious; behavioral development.

Copyright (c) 2021 Ika Juhriati, Azi Matur Rahmi

$\triangle$ Corresponding author:

Email Address : ka.juhriati@pelitabangsa.ac.id (Bekasi, Indonesia)

Received 15 April 2021, Accepted 26 April 2021, Published 04 August 2021 


\section{PENDAHULUAN}

Anak usia dini adalah merupakan asset bangsa yang sangat berharga merupakan generasi yang akan memimpin bangsa dimasa depan. Baik buruknya nasip bangsa dimasa depan tergantung dari kualitas anak-anak bangsa saat ini. Semakin baik kualitas anak maka semakin baik pula kualitas bangsa. Menyadari pentingnya kualitas anak maka studi ini adalah untuk mendeskripsikan bagaimana implementasi perkembangan nilai agama dan moral melalui metode esensi pembinaan perilaku pada anak usia dini. Salah satu sikap dasar yang harus dimiliki seorang anak untuk menjadi seorang manusia yang baik dan benar adalah memiliki sikap dan nilai yang baik dalam berperilaku (Suryana, 2018). Anak usia dini adalah individu yang sedang mengalami proses pertumbuhan dan perkembangan yang sangat pesat, bahkan dikatakan sebagai lompatan perkembangan. Anak usia dini memiliki rentang usia yang sangat berharga dibandingkan usia-usia selanjutnya karena perkembangan kecerdasannya sangat luar biasa (Mulyasa, 2012).

Anak usia dini adalah anak yang berusia 0 hingga 6 tahun yang melewati masa bayi, masa batita, dan masa prasekolah. Pada setiap masa yang dilalui oleh anak usia dini akan menunjukkan perkembangannya masing-masing yang berbeda antara masa bayi, masa batita dan masa praseklah. Anak usai dini merupakan periode awal merupakan periode awal yang paling penting dan mendasar sepanjang rentang pertumbuhan serta perkembangan kehidupan manusia. Pada masa ini ditandai oleh berbagai periode penting yang frudenmental dalam kehidupan anak selanjutnya sampai periode akhir perkembangannya. Salah satu yang menjadi ciri usia dini adalah periode keemasan (Novan Ardy Wiyani, 2016).

Pendidikan anak usia dini merupakan pendidikan yang diselenggarakan untuk mengembangkan seluruh potensi yang dimiliki anak secara optimal. Suyadi \& Ulfah (2013) menyatakan Pendidikan Anak Usia Dini (PAUD) pada hakikatnya ialah pendidikan yang diselenggarakan dengan tujuan untuk memfasilitasi pertumbuhan dan perkembangan anak secara menyeluruh atau menekankan pada pengembangan seluruh aspek kepribadian anak. Pendidikan anak usia dini merupakan dasar bagi pembentukan kepribadian manusia secara utuh, yaitu ditandai dengan karakter, budi pekerti luhur, pandai dan terampil. Pendidikan anak usia dini harus berlandasan pada kebutuhan anak, yang disesuaikan dengan nilaipnilai yang dianut dilingkungan sekitarnya (Yaswinda et al., 2018).

Pengembangan moral agama sangat erat kaitannya dengan budi pekerti, sikap sopan santun, dan kemauan melaksanakan ajaran agama dalam kehidupan sehari-hari. Pembahasan filosofis yang di kemukakan oleh Kilpatrick pendidikan moral akan terus berkembang dengan berbagai pendapat pakar dalam aspek budi pekerti, nilai moral dan keagamaan (Anggraini \& Syafril, 2018).

Pengembangan aspek nilai-nilai agama dan moral anak usia dini dilakukan dengan kegiatan pembiasaan rutin dan keteladanan yang dilakukan oleh anak sehari-hari membuat seorang pendidik harus merancang kegiatan pembelajaran yang lebih terprogram apalagi menyangkut media dalam pembelajarannya. Ini sangat berpengaruh karena pembelajaran anak usia dini masih dalam kondisi bermain yang perencanaannya meliputi hal-hal yang menarik dan menyenangkan bagi anak. Media akan sangat menunjang perkembangan aspek perkembangan pada anak (Supriyanto, 2015).

Pendidikan merupakan kebutuhan dasar manusia yang harus dipenuhi. Degan adanya proses pendidikan diharapkan terlahir manusia yang baik. Pendidikan menjadi media untuk memuliakan manusia dengan perkembangannya emampuan yang dimiliki oleh manusia, maka semakin tercerminlah kemuliaan manusia dan hakikat manusianya. Pendidikan sangat penting dalam proses perngembangan berbagai potensi yang dimiliki oleh manusia (Yazid, 2012).

Guru sebagai kemponen bertanggung jawab dalam proses dan isi pendidikan secara umum serta proses pembelajaran secara khusus, sangat rentan sebagai persoalan yang mungkin akan muncul bila rencana awal proses pembelajaran ini tidak terencana dengan matang dan bijak, hal ini akan berakibat dalam proses pembelajaran. Dalam hal ini, untuk 
membentuk kepribadian anak yang salih dan salihah. guru tidak cukup hanya memberikan nasehat saja, kerena lebih pening bagi anak adalah esensi pembinaan prilaku yang menerapkan nasehat tersebut. Sehingga sebanyak apapun nasehat yang diberikan tanpa disertai pembinaan maka akan menjadi sesuatu yang tidak bermakna. Perlunya pengembangan nilai agama dan moral dimulai sejak usia dini. Misalnya guru atau orang tua membiasakan anak-anak untuk berprilaku sopan seperti mencim tangan kedua orang tua ketika berjabat tangan, mengucapkan salam ketika berangkat dan mau berbagi mainanpemberi maaf, tidak pemarah, mau berkerja sama maka dengan sendirinya prilaku itu menjadi suatu kebiasaan anak dalam kehidupan sehari-hari (Wibowo, 2012). Terkait dengan perkembangan moral anak, Nauli et al. (2019) mendapati pola asuh budaya setempat juga berpengaruh terhadap pola asuh yang ibu selaku orang tua berikan demi tercapainya perkembangan moral anak. Masih diperlukan tingkat pemahaman yang baik guru dan orang tua agar pengembangan kecerdasan moral anak dapat lebih berkembang secara optimal (Sofia et al., 2020).

Perkembangan nilai agama dan moral anak dapat dikembangagkan dengan berbagai metode seperti bercerita (Kusnilawati et al., 2018; Umayah, 2016), mendongeng (Pebriana, 2017), permainan tepuk (Fauziddin \& Mufarizuddin, 2018), dan lain lain. Sehingga banyak alternatif yang dapat digunakan.

Adapun pada TK implementasi nilai agama dan moral tidak berjalan begitu saja dengan mulus, terkadang terdapat kendala yang dialami guru maupun siswa, seperti kurang bervariasinya guru terhadap mengimplementasikan nilai agama dan moral pada anak usia dini. Berdasarkan permasalahan tersebut maka penelitian yang akan peneliti teliti tentang implementasi nilai agama dan moral pada anak usia dini di Taman Kanak-Kanak Laboratorium School Universitas Negeri Padang.

\section{METODOLOGI}

Jenis penelitian ini adalah dengan menggunakan pendekatan kualitatif. Format deskriptif kualitatif pada umumnya dilakukan pada penelitian yang berbentuk studi kasus. Moleong (2017) menyatakan bahwa penelitian kualitatif adalah pada pengumpulan data pada suatu latar ilmiah dengan menggunakan metode alamiah, dan dilakukan oleh orang atau peneliti yang tertarik secara alamiah. Deksriptif adalah data yang dikumpulkan adalah berupa kata-kata, gambar, dan bukan angka-angka. Hal ini disebabkan oleh adanya penerapan metode kualitatif, selain itu, semua dikumpulkan berkemungkinan menjadi kunci terhadap apa yang sudah diteliti. Penelitian dilakukan dengan menggunakan tiga langkah pengumpulan data yaitu observasi, wawancara dan dokumentasi.

Deskripsi kajian temuan, yaitu mengkaji kurikulum Taman Kanak-kanak dengan melihat implementasi nilai agama dan moral melalui metode esensi pembinaan perilaku di Taman Kanak-kanak Lab. School Universitas Negeri Padang. Langkan pengumpulan data dapat dilihat pada gambar 1.
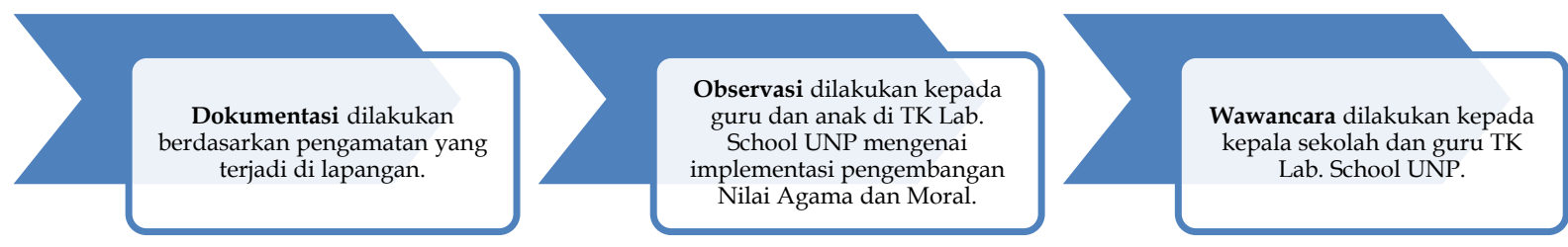

Gambar 1. Desain pengumpualan data penelitian

Selanjutnya dilakukan teknik pengabsahan data yaitu pengumpulan data, reduksi data, penyajian data, dena menarik kesimpulan (Sugiyono, 2013). Penelitian ini berbentuk studi laporan (field research) yang bersifat deksriptif yaitu menggambarkan apa adanya atau memberikan gambaran lebih jelas tentang kajian implementasi nilai agama dan moral anak di 
Taman Kanak-kanak Laboratorum Pembangunan Universitas Negeri Padang. TK ini memiliki staf pengajar 8 orang dan 1 kapala sekolah. Pembelajaran dimulai dari pukul $08.00 \mathrm{wib}$, dan memiliki 4 kelas yang mana diantaranya 1 kelas TKA, 4 kelas TKB. Menurut Moleong (2016) untuk memasuki pekerjaan dilapangan, peneliti perlu memahami latar penelitian terlebih dahulu. Dalam hal ini peneliti telah melakuakan observasi terlebih dahulu untuk memahami latar tempat penelitian. Sehingga dapat mempermudah peneliti mengetahui berbagai aspek yang diteliti yaitu implementasi pengembangan nilai agama dan moral pada anak usia dini melalui metode esensi pembinaan prilaku di Taman Kanak-Kanak Laboratorium Pembangunan Universitas Negeri Padang.

\section{HASIL DAN PEMBAHASAN Mengenalkan Tuhan}

Dalam mengembangkan nilai agama dan moral melalui metode esensi pembinaan prilaku pada anak yaitu anak telah dibiasakan untuk mengenalkan tuhannya yaitu anak diajarkan untuk mengenal ciptaan Allah, sehingga anak dapat mengetahui siapa yang menciptakan langit dan bumi. Guru melakukan bentuk pengembanga pengenalan ciptaan tuhan, seperti manusia siapa yang menciptakan, hewan, tumbuh-tumbuhan dan lain-lain sehingga anak di biasakan dengan prilaku pembinaan sampai anak benar-benar mengerti tentang bagai nama kegidupan yaitu melakukan suruhan Allah dan menjauhi larangan Allah.

Berdasarkan hasil wawancara peneliti tentang kajian implementasi nilai agama dan moral anak di Taman Kanak-kanak Laboratorum Pembangunan UNP yaitu khususnya dalam menganalkan Tuhan. Wawancara dilakukan dengan Ibu AR yaitu "cara atau penerapan kami tentang bagaimana pengenalan tuhan pada anak yaitu dengan memberikan komunikasi kepada anak bahwa Tuhan itu benar-benar ada, semua seisi bumi dan langit adalah ciptaan Allah. Bahkan manusia, hewan dan tumbuhan adalah ciptaan Allah dan kita sebagai manusia wajib melaksanakan perintah dan menjauhi yang dilarang Allah" Melakukan bentuk-bentuk pengenalan tuhan kepada anak yaitu anak mampu mengingat beberapa kisah-kisah nabi dan rasul serta tugas malaikat Allah dan nama-nama rasul Allah dan tugas malaikat. Pelaksanaan pembelajaran tersebut diilustrasikan pada gambar 1. Jadi dengan pengenalan tersebut anak dapat terbiasa dengan ajaran-ajaran Allah dengan begitu anak selalu mengenal siapa yang menciptakan dirinya sendiri dan mengerti ciptaan-ciptaan tuhan.

\section{Mengenalkan Ibadah Kepada Allah.}

Dalam mengembangkan nilai agama dan moral melalui metode esensi prilaku yaitu guru memberikan komunikasi kepada anak, memberikan arahan kepada tentang ibadah, sehingga anak menjadi teribiasa untuk beribadah. Contohnya sholat, sedekah dan lain-lain sebagainya.

Guru mengenalkan ibadah kepada anak dengan menyembah Allah serta menyeru untuk senantiasa mengingat Allah. Dengan begitu anak menyembah kepada sang pencipta dirinya sendiri dan seluruh seisi bumi. Kemudian mengajarkan anak membaca Iqro' dan menjelaskan kepada anak agar kelak dapat membaca Al-qur'an karana Al-qur'an adalah petunjuk bagi umat manusia.

Berdasarkan hasil wawancara peneliti tentang kajian implementasi nilai agama dan moral anak di Taman Kanak-kanak Laboratorum Pembangunan UNP yaitu khususnya dalam menganalkan ibadah kepada Allah. Wawancara dilakukan dengan Ibu AR yaitu "melakukan praktek sholat berjamaan sebagai kewajiban kita sebagi makhluk ciptaan tuhan. Anak-anak diajarkan dalam melakukan sholat, gerakan sholat serta bacaan dalam sholat. Tata cara berwudu' dan tata cara adzan. Anak dilibatkan dalam pengajaran praktek sholat. Setelah itu diajarkan juga membaca iqro'. “

Senada dengan temuan ini Wahyuni \& Purnama (2020) menggunakan kisah qur'ani dalam mengenalkan perbadatan dan karakter anak yaitu; mengenal agama yang dianut, mengerjakan ibadah, berperilaku jujur, penolong, hormat, sportif, menjaga kebersihan diri dan lingkungan, mengetahui hari besar agama, menghormati (toleransi) 
Dapat disimpulkan bahwa guru melakukan kerja sama dalam mengajarkan anak untuk mengenalkan ibadah kepada Allah SWT sehingga anak mampu dalam belajar kebaikan. Implementasi pelaksanaan ibadah dapat dilihat pada gambar 2.

\section{Mananamkan akhlak yang baik}

Dalam pengembangan nilai agama dan moral melalui metode esensi prilaku yaitu menanamkan akhlak yang baik, memberikan contoh teladan kepada anak agar anak dapat meniru prilaku baik dari gurunya sendiri sehingga anak dapat bertata moral yang baik.

Berdasarkan hasil wawancara peneliti tentang kajian implementasi nilai agama dan moral anak di Taman Kanak-kanak Laboratorum Pembangunan UNP yaitu khususnya dalam menanamkan akhlak baik. Wawancara dilakukan dengan Ibu AR yaitu "dalam menanamkan akhlah kepada anak tentu guru terlebih dahulu memberikan contoh kepada anak Karen pada dasarnya guru adalah sebegai teladan bagi anak. Kemudian anak diberikan pembeiasaan untuk berprilaku baik seperti tolong menolong, menolong teman yang sedang kesusahan dan dalam pembelajaran anak diajarkan berbagi dengan teman, seperti berbagi mainan dan makanan. "

Menanamkan prilaku akhlak yang baik kepada anak yaitu dengan mengompakkan anak sehingga anak mampu bekerja sama dan tolong menolong antar sesama teman. Dan menjelaskan kepada anaka saling menghormati antar sesama ciptaan Allah seperti menyayangi binang dan menjaga tumbuhan dan tidak merusaknya. Sehingga dengan begitu memberikan pemahaman kepada anak sehingga anak dapat membedakan yang baik dan yang buruk.

Dapat disimpulkan metode ynag digunakan dalam menanamkan akhlak yang baik kepada anak yaitu memberikan pengarahan serta mengkomunikasikan kepada anak serta menberikan contoh teladan yang baik secara tidak langsung anak akan mengikuti gerak-gerik setiap hal yang dilakukan dan dicontohkan oleh guru. Gambaran perilaku hasil implementasi moral diilustrasikan pada gambar 3.

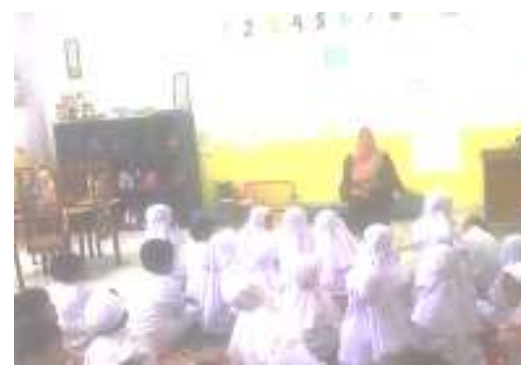

Gambar 1. Pembelajaran pengenala ciptaan Tuhan.

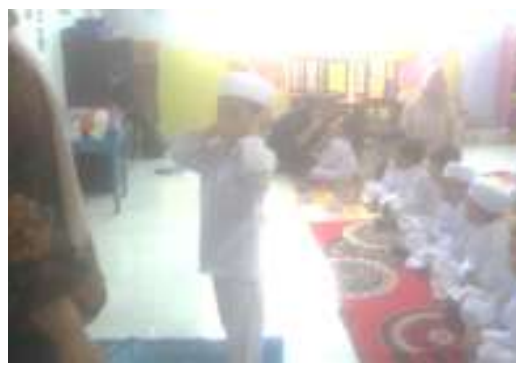

Gambar 2. Praktek sholat berjamaah.

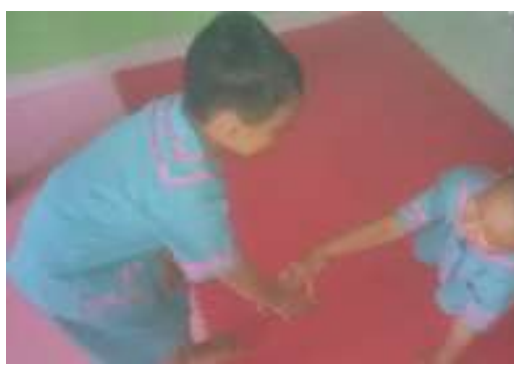

Gambar 3. Menolong teman terjatuh

\section{Pembahasan}

Berdasarkan hasil temuan di lapangan mengenai implementsi nilai agama dan moral pada anak usia dini melalui metode esensi pembinaan prilaku di Taman Kanak-kanak Laboratorium Universitas Negeri Padang. Berdasarkan hasil observasi, wawancara dan dokumentasi yaitu dilakukan dengan mengenalkan Tuhan, Mengenalkan ibadah kepada Allah, dan menanamkan akhlak yang baik. Hal ini sejalan bahwa Anak usia dini merupakan periode awal yang paling penting dan mendasar sepanjang rentang pertumbuhan serta perkembangan manusia Masa-masa rentangan usia dini merupakan masa emas dimana perkembangan fisik, motorik, intelektual, emosional, bahasa dan sosial berlangsung dengan sangat cepat. Dari lahir sampai kurang lebih dua tahun perkembangan anak sangat berkaitan dengan keadaan fisik dan kesehatannya (Novan Andri Wiyani, 2013). Lebih lanjut Nurwita (2019) menambahkan, sebaiknya guru dan orang tua memberikan ruang lingkup pengembangan nilai-nilai agama kepada anak dimulai dari kebutuhan anak tentang rutinitas kehidupan pribadi anak mulai dari mereka bangun tidur sampai tidur kembali. Sedangkan 
menurut Khasanah \& Fauziah (2020) perkembangan moral anak dimulai dari lingkungan mikro, yaitu keluarga. Sehingga penting untuk melatih aspek sosial dan moral anak.

Anak usia dini memiliki karakteristik yang unik karena mereka berada pada proses tumbuh kembang sangat pesat dan fundamental bagi kehidupan berikutnya. Secara psikologis anak usia dini memiliki karakteristik yang khas dan berbeda dengan anak yang usianya di atas delapan tahun (Fadlillah \& Khorida, 2013). Dalam pengembangan pada anak usia dini hendaknya memiliki nilai-niai. Menurut Suyadi \& Ulfah (2013) nilai agama dan moral adalah ukuran baik-buruknya seseorang, baik sebagai pribadi warga masyarakat, dan warga negara. Sedangkan pendidikan moral adalah pendidikan untuk mejadikan anak yang manusia yang bermoral manusiawi.

Perkembangan nilai agama dan moral merupakan salah satu aspek perkembangan anak yang sangat berpengaruh dalam mencapai pertumbuhan dan tujuan pendidikan. Karena nilai agama dan moral merupakan kemampuan untuk menentukan benar dan salah serta baik dan buruknya tingkah laku atau karakter yang mempunyai hubungan tidak terrpisahkan dengan sikap social, sehingga dalam hubungannya dengan tujuan pendidikan nasional adalah dengan memiliki perilaku moral yang sesuai dengan nilai -nilai agama, maka akan tercipta peserta didik yang bermoral sesuai dengan etika dalam bertingkah laku, (Anggraini \& Syafril, 2018).

Nilai agama dan moral pada anak usia dini merupakan perubahan psikis yang dialami oleh anak usia dini terkait dengan kemampuannya dalam memahami dan melakukan perilaku yang baik. Adapun nilai agama dan moral merupakan pondasi awal dalam membenahi diri untuk mengatasi kemungkinan-kemungkinan buruk yang akan mereka jumpai dikehidupan sehari-hari (Tanfidiyah, 2017).

\section{SIMPULAN}

Implementasi pengembangan nilai gama dan moral pada anak usia dini melalui metode esensi pembinaan prilaku di Taman Kanak-Kanak Laboratorum Pembangunan UNP telah dilaksanakan dengan baik, terlihat dari cara anak mengenal tuhan, mengenal ibadah kepada Allah SWT, serta berakhlak yang baik. Hasil observasi yang telah dilakukan cocok dengan hasil wawancara dengan guru dalam membina perilaku anak. Guru mengembangkan perilaku anak melalui pembiasaan seperti melaksanakan nilai-nilai ajaran agama (beribadah), serta membina dan hubungan terhadap lingkungan. Komunikasi kepada anak berupa memberikan bimbingan, arahan, pengawasan. dan memberi contoh yang baik.

\section{UCAPAN TERIMA KASIH}

Ucapan terima kasih kepada Kepala Taman Kanak-Kanak Laboratorum Pembangunan Universitas Negeri Padang yang telah memberikan kesempatan untuk penelitian ini dan semua pihak yang telah membantu sehingga tulisan ini dapat dipublikasikan. Semoga artikel ini dapat bermanfaat bagi perkembangan keilmuan, utamanya pada pendidikan anak usia dini.

\section{DAFTAR PUSTAKA}

Anggraini, W., \& Syafril, S. (2018). Pengembangan Nilai-Nilai Moral dan Agama pada Anak Usia Dini. Jurnal Pendidikan Anak Usia Dini, 3(1). https://doi.org/10.31219/osf.io/dbnya

Fadlillah, M., \& Khorida, L. M. (2013). Pendidikan karakter anak usia dini. Jogjakarta: Ar-Ruzz Media, 25.

Fauziddin, M. dan M., \& Mufarizuddin, M. (2018). Useful of Clap Hand Games for Optimalize Cogtivite Aspects in Early Childhood Education. Jurnal Obsesi : Jurnal Pendidikan Anak Usia Dini, 2(2), 162. https://doi.org/10.31004/obsesi.v2i2.76 
Khasanah, B. L., \& Fauziah, P. (2020). Pola Asuh Ayah dalam Perilaku Prososial Anak Usia

Dini. Jurnal Obsesi: Jurnal Pendidikan Anak Usia Dini, 5(1), 909-922. https:// doi.org/10.31004/obsesi.v5i1.627

Kusnilawati, K., Fauziddin, M., \& Astuti, A. (2018). Meningkatkan Aspek Perkembangan Nilai Agama dan Moral Anak Usia Dini dengan Penerapan Metode Bercerita Tema Islami.

Aulad: Journal on Early Childhood, 1(1), 28-38. https:/ / doi.org/10.31004/aulad.v1i1.4 Moleong, L. J. (2016). Metodologi Penelitian Kualitatif. PT. Remaja Rosdakarya.

Moleong, L. J. (2017). Metodologi Penelitian Kualitatif (Edisi Revisi). PT. Remaja Rosdakarya. Mulyasa, H. E. (2012). Manajemen Paud. Bandung: Remaja Rosdakarya.

Nauli, V. A., Karnadi, K., Meilani, S. M., \& Nauli, V. A., Karnadi, K., \& Meilani, S. M. (2019). Peran Ibu Pedagang Pasar 24 Jam Terhadap Perkembangan Moral Anak (Penelitian Studi Kasus di Kota Bekasi). Jurnal Obsesi : Jurnal Pendidikan Anak Usia Dini, 3(1), 241. https://doi.org/10.31004/obsesi.v3i1.179

Nurwita, S. (2019). Analisis Nilai-Nilai Agama dan Moral Anak Usia Dini dalam Tayangan Film Kartun Upin dan Ipin. Jurnal Obsesi : Jurnal Pendidikan Anak Usia Dini, 3(2), 506. https://doi.org/10.31004/obsesi.v3i2.252

Pebriana, P. H. (2017). Analisis Kemampuan Berbahasa dan Penanaman Moral pada Anak Usia Dini melalui Metode Mendongeng. Jurnal Obsesi : Jurnal Pendidikan Anak Usia Dini, 1(2), 139-147. https:/ / doi.org/10.31004/obsesi.v1i2.25

Sofia, A., Nopiana, N., \& Suryadi, S. (2020). Study Deskriptif Faktor-Faktor Penunjang Dan Penghambat Pengembangan Kecerdasan Moral Anak Usia Dini 5-6 Tahun. Jurnal Obsesi: Jurnal Pendidikan Anak Usia Dini, 5(1), 599. https://doi.org/10.31004/obsesi.v5i1.467

Sugiyono. (2013). Metode Penelitian Pendidikan Pendekatan Kuantitaif, Kualitatif, dan R\&D. In Metode Penelitian Pendidikan Pendekatan Kuantitaif, Kualitatif, dan R\&D (pp. 85, 221, 273). CV. Alfabeta.

Suryana, D. (2018). Stimulasi dan Aspek Perkembangan Anak. Prenadamedia Grup. Suyadi, \& Ulfah, M. (2013). Konsep Dasar PAUD. In Bandung: PT Remaja Rosdakarya.

Tanfidiyah, N. (2017). Perkambangan Agama dan Moral yang tidak Tercapai pada AUD: Studi Kasus di Kelas A1 TK Masyitoh nDasari Budi Yogyakarta. Nadwa, 11(2), 199. https:// doi.org/10.21580/nw.2017.11.2.1810

Umayah. (2016). Menanamkan Moral dan Nilai-nilai Agama pada Anak Usia Dini Melalui Cerita. Jurnal Pendidikan Guru Raudlatul Athfal, 1(1), 96-105. https:// doi.org/10.31004/obsesi.v1i1.28

Wahyuni, S., \& Purnama, S. (2020). Pengembangan Religiusitas melalui Metode Kisah Qur'ani di Taman Kanak-Kanak. Jurnal Obsesi : Jurnal Pendidikan Anak Usia Dini, 5(1), 103. https:// doi.org/10.31004/obsesi.v5i1.523

Wibowo, A. (2012). Pendidikan Karakter AUD. PT Pustaka Pelajar.

Wiyani, Novan Andri. (2013). Bina Karakter Anak Usia Dini. Yogyakarta. In Ar-Ruzz Media. Ar Ruzz Media.

Wiyani, Novan Ardy. (2016). Konsep Dasar PAUD. gava media.

Yaswinda, Y., Yulsyofriend, Y., \& Mayar, F. (2018). Pengembangan Bahan Pembelajaran Sains Berbasis Multisensori Ekologi Bagi Guru Paud Kecamatan Tilatang Kamang Kabupaten Agam. Yaa Bunayya: Jurnal Pendidikan Anak Usia Dini, 2(2), 13-22.

Yazid, M. B. (2012). Panduan Lengkap PAUD Melejitkan Potensi dan Kecerdasan Anak Usia Dini. 